\title{
STUDY OF THE BLOOD IN CHRONIC RESPIRATORY DIS- EASES, WITH SPECIAL REFERENCE TO THE VOLUME OF THE BLOOD ${ }^{1}$
}

\author{
By NOLAN L. KALTREIDER, ALBERTO HURTADO AND \\ WILLIAM D. W. BROOKS 2 \\ (From the Department of Medicine of the School of Medicine and Dentistry of the \\ University of Rochester and the Medical Clinic of the Strong Memorial and \\ Rochester Municipal Hospitals, Rochester, New York)
}

(Received for publication August 6, 1934)

The character of the changes in the blood in cases of chronic pulmonary diseases has not been settled. Although patients with respiratory disturbances often have the appearance of those with polycythemia, it is questionable whether there is an actual increase in the blood and cell volume. Some investigators believe that the blood in these cases shows a polycythemic picture, which they believe to be due to interference with the proper pulmonary exchange of oxygen, resulting in a low tension of oxygen in the arterial blood which in turn overstimulates the bone marrow. The usual response of the blood to low oxygen tensions obtained for short periods under experimental conditions has been studied extensively. But investigations of the changes occurring in cases of chronic pulmonary diseases with or without anoxemia due to faulty pulmonary exchange are not available except in a few isolated cases. We have attempted to clarify this problem by studying a group of cases with chronic pulmonary diseases; determining not only the characteristics of the erythrocytes and the blood volume but also correlating these findings with various factors such as arterial oxygen saturation, the pulmonary capacity and its sub-divisions and the duration and severity of the disease. We feel that these observations of the volume and morphology of the blood are enhanced by other studies, to be reported later, which we have made on these patients in order better to classify and understand their functional pathology.

Well established standards of the normal morphology of the red blood cells are available in the literature, but the values for the blood volume reported by different observers, using similar technique and experimental conditions, vary markedly. We have collected in Table $I$ the values for

1 The expenses of this investigation were defrayed from a fund contributed by the Corning Glass Company, The Eastman Kodak Company, The American Grinding Wheel Manufacturing Association, The American Laundry Machinery Company, The Gleason Works, The Symington Company and the Pfaudler Company.

2 Travelling Fellow of the Rockefeller Foundation; Ferëday Fellow, St. John's College, Oxford. 


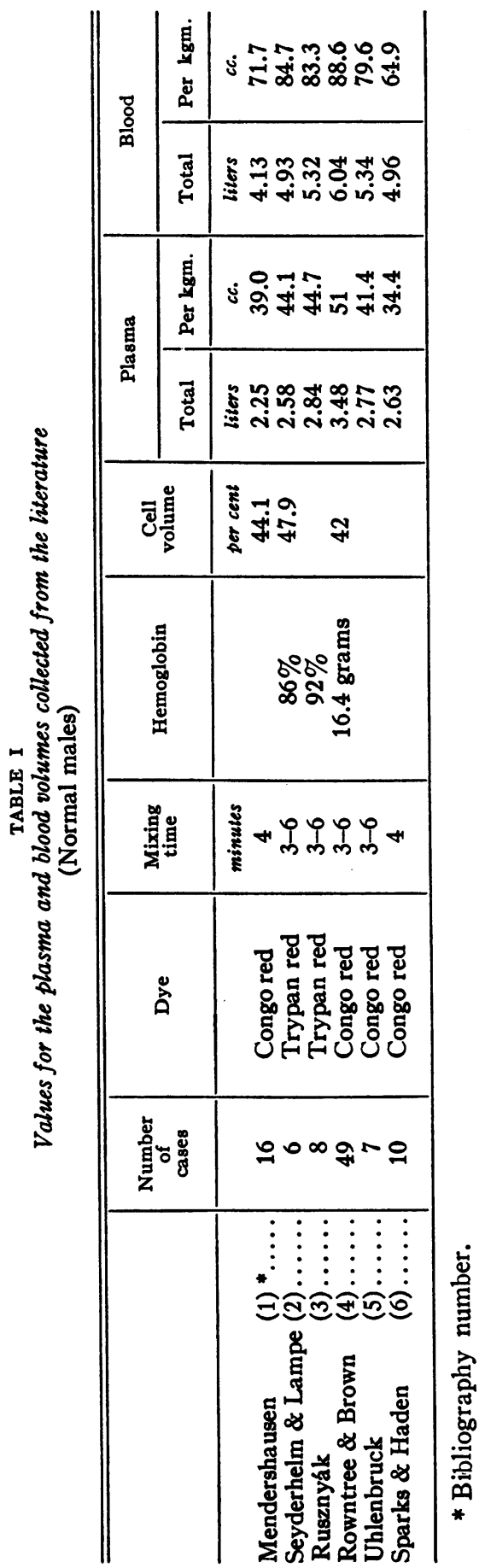


the plasma and blood volume in normal male subjects reported in the literature, including only those reports dealing with the larger number of cases. All these determinations, in normal male subjects of various age groups were made by injecting a dye into the peripheral blood stream according to the method first introduced by Keith, Rowntree and Geraghty (7). The plasma volume has been variously estimated from $34 \mathrm{cc}$. to $51 \mathrm{cc}$., per kilogram and the volume of blood, from $72 \mathrm{cc}$. to $89 \mathrm{cc}$. per kilogram of body weight. Fleischer-Hanson (8), who objects to the above procedure because of inadequate mixing of the blood and dye in the time allowed, has the subject perform the so-called "mixing movements" and finds the volume of the blood as low as $49 \mathrm{cc}$. per kilogram. Because of this wide variation it was felt necessary to determine our own standards for normal individuals in order to have a basis for evaluating our study of pathological cases. A review of the literature also indicates that one must allow generous limits for normal variation.

\section{METHODS}

In this investigation the dye method of Keith, Rowntree and Geraghty (7) with the modifications as described by Hooper, Smith, Belt and Whipple (9) was used for determining the plasma volume. All the observations were made with the patient in the recumbent position, following a fast of twelve hours. A needle was inserted into the antecubital vein and 12 to $15 \mathrm{cc}$. of blood were removed without stasis. About $3 \mathrm{cc}$. of the blood were placed in an oxalated tube for hemoglobin determination, while the remaining 8 to $10 \mathrm{cc}$. of blood were placed in a centrifuge tube accurately calibrated to tenths of a cubic centimeter and containing $2 \mathrm{cc}$. of 1.6 per cent solution of sodium oxalate. The tube was stoppered and inverted several times to prevent clotting. Without removing the needle from the vein, a 1.5 per cent solution of brilliant vital red, freshly prepared and filtered, was injected into the blood stream. In each case four milligrams of the dye per kilogram body weight were introduced. Four minutes after the injection, 8 to $10 \mathrm{cc}$. of blood were removed from the antecubital vein of the opposite arm. This blood was placed in another graduated centrifuge tube containing $2 \mathrm{cc}$. of 1.6 per cent solution of sodium oxalate. This was stoppered, inverted and, along with the other tube, was centrifuged at 2700 revolutions per minute for 45 minutes. Then the hematocrit and other readings necessary for the calculation of the plasma volume were made. The standard, made from the filtered solution, and the unknown solution were then prepared for colorimetric comparison. The volumes of the plasma and blood were calculated according to the formulas derived by Hooper, Smith, Belt and Whipple (9). In all cases the hemoglobin concentration was determined on the first sample of blood by measuring the oxygen combining power according to 
Van Slyke's method (10). It is possible to calculate the corpuscular volume and hemoglobin per $100 \mathrm{cc}$. of blood. We have not encountered a single reaction to the injection of the dye in $\mathbf{5 5}$ determinations.

The oxygen content and combining power of the arterial blood were determined in the Van Slyke manometric apparatus.

The total pulmonary capacity and its sub-divisions were measured according to the methods used in this clinic $(11,12)$.

\section{DETERMINATIONS ON NORMAL SUBJECTS}

The volumes of the plasma and blood were estimated on 25 normal male subjects, who were students in this University. No selective criteria as to physical characteristics were used save that the subjects were free from any discernible disease. A clinical history was obtained from each individual and a physical examination made.

The physical characteristics and the values for the blood volume and its components of these subjects are summarized in Table II. The weight observed in this group corresponds closely with the average ideal weight calculated from age and height.

TABLE II

The volumes of the plasma and blood in 25 normal males with age and physical characteristics of the subjects

(Dye method-Brilliant vital red)

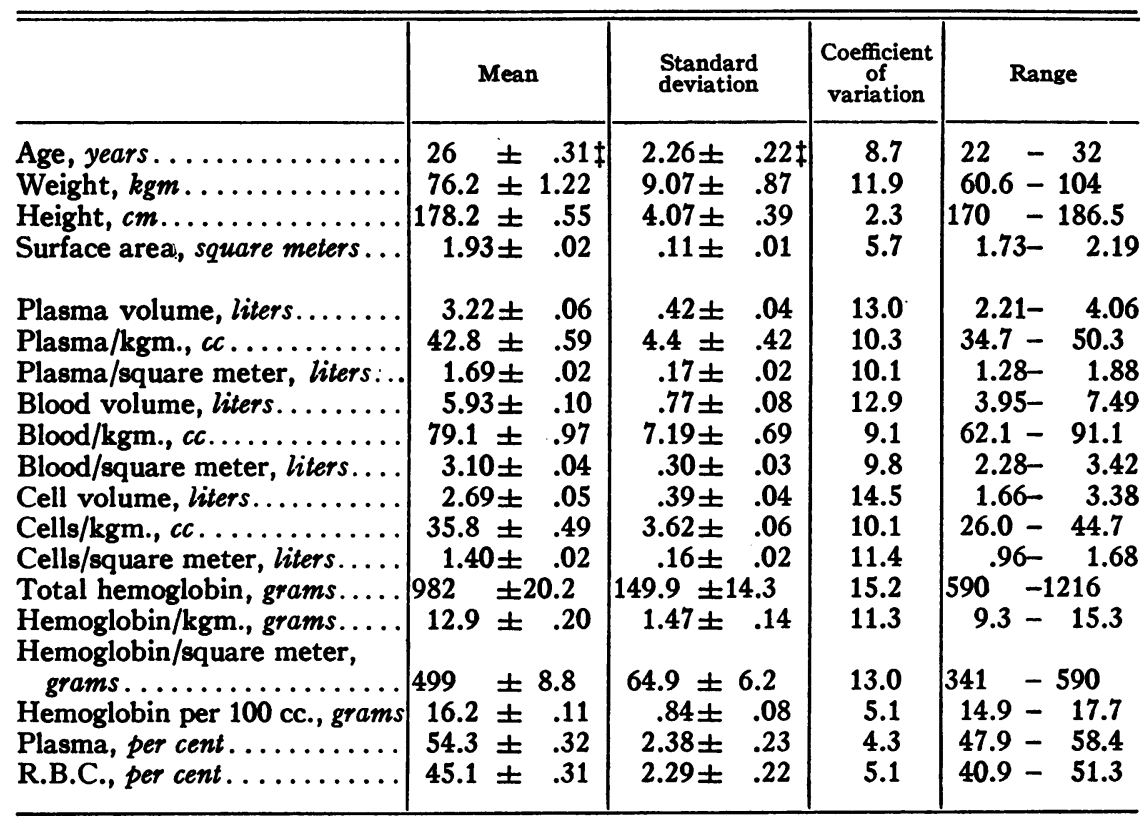

$\ddagger$ Probable error. 
The mean value of the plasma volume was 3.22 liters with variation between 2.21 and 4.06 liters, while the plasma per kilogram of body weight was $42.8 \mathrm{cc}$., a value just about midway between the lowest and the highest values reported in the literature.

The blood volume was observed to vary markedly both in total volume and volume per kilogram of body weight. The mean value of the former was 5.93 liters varying from 3.95 to 7.49 liters, while that of the latter was $79.1 \mathrm{cc}$. with variation between 62.1 and $91.1 \mathrm{cc}$. The mean value for blood volume per kilogram of body weight was again found to be about midway between the extremes in the literature.

The total volume of the cells and total hemoglobin varied markedly from individual to individual. The mean value for the cell volume was 2.69 liters while the value for each kilogram of body weight was $35.8 \mathrm{cc}$. The mean value for the hemoglobin per kilogram of body weight was 12.9 grams, a figure almost two grams lower than that reported by Rowntree and Brown (4) in a similar group of cases.

The mean value for the red blood cell percentage was 45.1 with variation between 40.9 and 51.3. Determinations of hemoglobin per $100 \mathrm{cc}$. of blood gave a mean value of 16.2 grams. These results correspond very closely with those collected from papers in the literature and reported by Wintrobe (13), who found in 381 cases (all males) that the average value for the hematocrit was 46.3 per cent and in 583 cases the hemoglobin per 100 cc. of blood was 16.0 grams.

The correlation of the blood volume and its components to body weight and body surface area is given in Table III. The most significant correlation exists between the body weight and the volume of the blood and its

TABLE III

Correlation of blood volume with various body measurements

\begin{tabular}{|c|c|}
\hline & $\begin{array}{l}\text { Correlation } \\
\text { coefficient }\end{array}$ \\
\hline 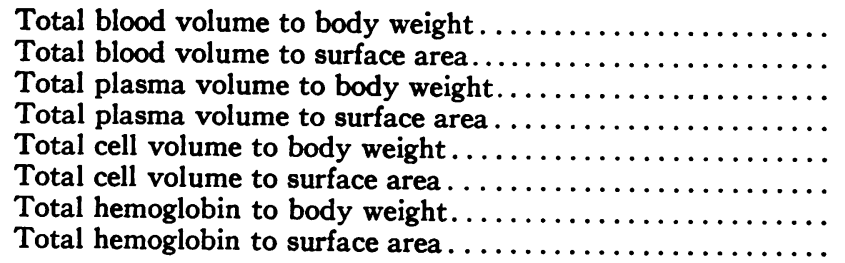 & $\begin{array}{l}.7297 \pm .0631 \ddagger \\
.6756 \pm .0733 \\
.6954 \pm .0697 \\
.6387 \pm .0798 \\
.8014 \pm .0483 \\
.7840 \pm .0519 \\
.7700 \pm .0549 \\
.7648 \pm .0560\end{array}$ \\
\hline
\end{tabular}

components. This finding indicates that knowing the body weight of an individual in kilograms one can predict the total blood volume with a fair degree of accuracy by means of the regression formula derived from the coefficient of correlation. ${ }^{3}$ From the predicted blood volume and the nor-

3 The regression formula is :

Total volume $=($ Kilograms body weight $\times 0.06)+1.41$. 
mal mean values for hematocrit and hemoglobin per $100 \mathrm{cc}$. of blood, one can calculate the expected cell and plasma volumes and the total hemoglobin. Rowntree and Brown (4) found the best correlation between surface area of the body and the plasma and blood volume.

The total plasma, blood and cell volume and the total hemoglobin of the 25 normal subjects were calculated from the regression formulas and compared with the observed values for the purpose of establishing the normal range of variability. Of the observed blood volumes 92 per cent fell within the limits plus and minus 15 per cent of the calculated values; while of the observed plasma and cell volumes and total circulating hemoglobin 88 per cent were within this same limit. Individual variations around plus and minus 15 per cent of the calculated may not be significant but when the mean value for a group of pathological cases approaches this limit, the difference becomes of some importance.

\section{DETERMINATIONS ON CASES WITH CHRONIC PULMONARY DISEASES}

\section{Literature}

Blood volume determinations have been made both by the carbon monoxide and dye methods on patients with chronic respiratory diseases. In five cases with chronic bronchitis, emphysema and asthma, studied by Plesch (14) the average blood volume by the carbon monoxide method was 72 cc. per kilogram of body weight. This was 35 per cent greater than the values which he found in nine normal subjects. These values are of course low when compared with those that one obtains by means of the dye method; a difference found repeatedly by many investigators. Uhlenbruck (5) using the dye method (congo red), confirmed the results of Plesch. He estimated the volume of the blood and plasma in 7 normal males and found mean values of $79.6 \mathrm{cc}$. and $41.4 \mathrm{cc}$. per kilogram of body weight respectively. In 8 male patients with emphysema and asthma this investigator found an average blood volume of $101 \mathrm{cc}$. per kilogram of body weight with extreme variations of 78 and $147 \mathrm{cc}$. and an average plasma volume of $53 \mathrm{cc}$. per kilogram, an increase in blood volume of 27 per cent and an increase in the plasma volume of 28 per cent. Lemon (15) reported 12 cases (11 males and 1 female) with pulmonary emphysema, in which he determined not only the volume of the plasma and blood but also the arterial oxygen saturation, the vital capacity and the characteristics of the erythrocytes. He found that the mean value for the blood volume per kilogram of body weight was only slightly higher $(4 \mathrm{cc}$.) than that of the normal group. In several cases there was evidence of increase in the concentration of the blood, i.e. increase in the volume of cells without increase in the blood volume. Along with the concentration of the blood he observed a definite increase in the hemoglobin content of the erythrocytes. Arterial blood was obtained in 7 cases and, in all, the satu- 
ration was less than 95 per cent. No correlation was demonstrated between the decrease in the oxygen saturation of the arterial blood and the alterations in the blood volume or between decrease in vital capacity and changes in the blood volume. None of the cases which he studied simulated polycythemia vera. So far as we can find no one has reported determinations of blood volume in a group of cases with pulmonary fibrosis.

\section{Material}

Determinations of plasma and blood volume and morphology of the cells were made in 16 cases with chronic pulmonary emphysema and in 14 cases of pulmonary fibrosis. The major purpose of this study was to attempt to correlate these findings with the clinical condition of the patient, the oxygen saturation of the arterial blood and the pulmonary capacity.

Emphysema. The 16 patients in this group had varying degrees of emphysema associated with chronic bronchitis, bronchiectasis or asthma. The physical characteristics, symptoms and signs, with interpretations of the roentgenograms of the chest are given in Table IV. The age of the individuals varied from 31 to 59 years. None of the patients was particularly obese; many of the subjects weighed less than their "ideal" weight calculated according to the height and age. The average weight of the group was 6 kilograms below that of their "ideal " weight. All of the patients except one complained of cough. Dyspnea was a symptom of all the subjects, and in two it was present during rest. All but three had asthmatic attacks. The duration of the symptoms varied from 1 to 25 years. None of the patients complained of nervous or psychic symptoms. Cyanosis was observed in half the cases; clubbing of the fingers was found in 6 of the 16 subjects. The spleen was not palpable in any of these individuals. The degree of emphysema was estimated from the relative values of the residual air and the total pulmonary capacity. The blood pressure was within normal limits in all subjects. The electrocardiogram was normal in all except Case 1 , in which there was evidence of myocardial damage, and in Cases 13,14 and 15, in which left ventricular preponderance was indicated.

Fibrosis. In 10 of the 14 cases, the fibrosis was suspected to be due to inhalation of silica. The etiology of the fibrosis in the remaining cases is not known. One patient had arteriosclerotic heart disease which was well compensated at the time of the examination; another, Case 22, had a secondary anemia. The clinical observations in this group of patients are summarized in Table V. The age of the subjects varied from 32 to 65 years. The average "ideal" weight of the group was 68.6 kilograms as compared with that of the observed which was 67.7 kilograms. A high percentage of the patients complained of cough and dyspnea, while only two of them (Cases 19 and 24) gave a history of asthma. The duration 


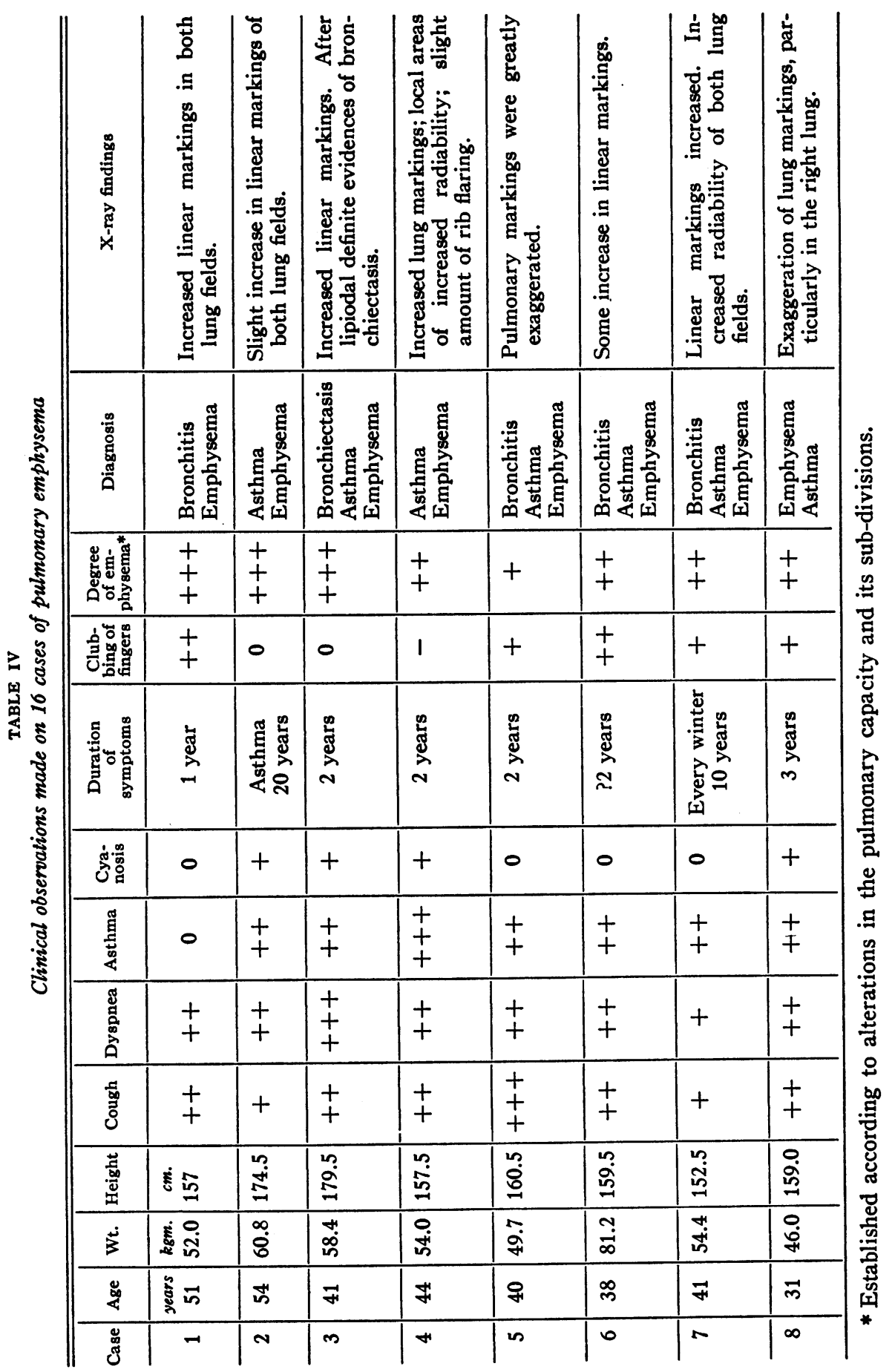


N. L. KALTREIDER, A. HURTADO AND W. D. W. BROOKS 1007

\begin{tabular}{|c|c|c|c|c|c|c|c|c|}
\hline 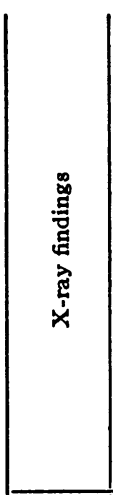 & 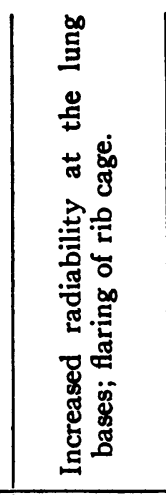 & 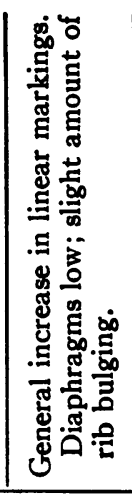 & 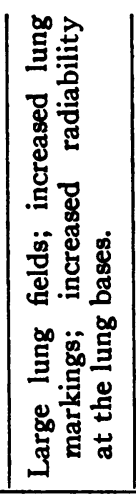 & 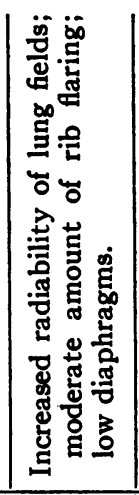 & 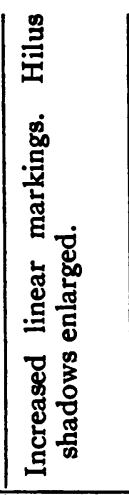 & 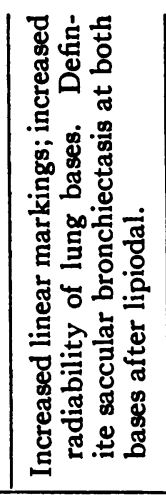 & 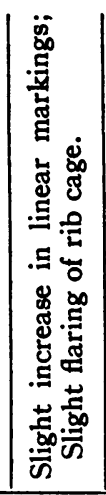 & 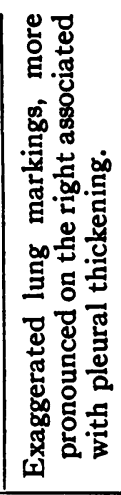 \\
\hline 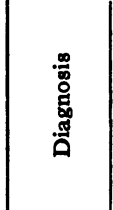 & 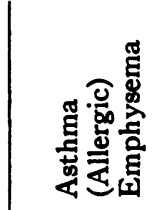 & 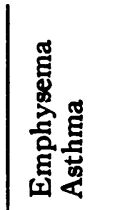 & 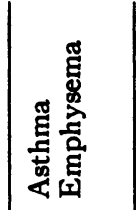 & 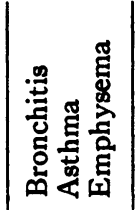 & 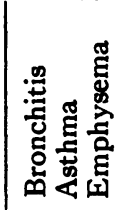 & 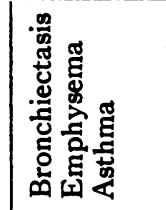 & 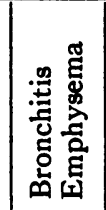 & 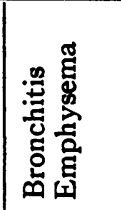 \\
\hline 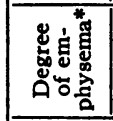 & + & $\begin{array}{l}+ \\
+ \\
+\end{array}$ & $\begin{array}{l}+ \\
+ \\
+\end{array}$ & + & + & + & + & + \\
\hline 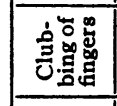 & 0 & 1 & 0 & 0 & 0 & + & 0 & 0 \\
\hline 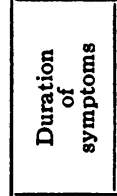 & 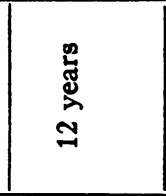 & 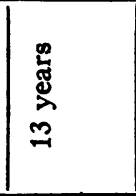 & 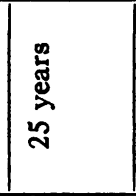 & 弯 & 足 & 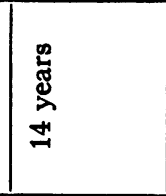 & 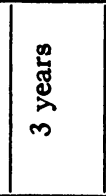 & 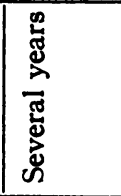 \\
\hline 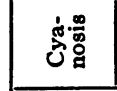 & 0 & + & + & 0 & + & + & 0 & 0 \\
\hline$\underset{\mathbb{E}}{\tilde{E}}$ & + & + & + & + & + & + & 0 & 0 \\
\hline 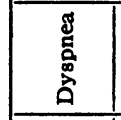 & + & + & $\begin{array}{l}+ \\
+ \\
+\end{array}$ & + & + & + & + & + \\
\hline 离 & 0 & + & + & $\mid \begin{array}{l}+ \\
+ \\
+\end{array}$ & + & $\stackrel{+}{+}$ & + & + \\
\hline 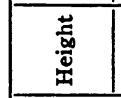 & है & 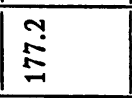 & مå & $\begin{array}{l}0 \\
0 \\
0\end{array}$ & $\stackrel{2}{\Xi}$ & 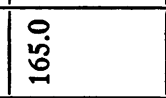 & ڤ艹 & 莫 \\
\hline$\dot{3}$ & క్ & 落 & $\tilde{\infty}$ & 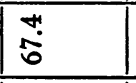 & \begin{tabular}{|l|l} 
\\
\end{tabular} & \begin{tabular}{|l|} 
\\
0 \\
0
\end{tabular} & 范 & 总 \\
\hline 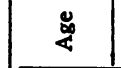 & 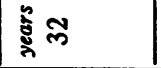 & $\$$ & is & in & \% & $\mid \stackrel{m}{\infty}$ & $\stackrel{\infty}{+}$ & 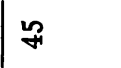 \\
\hline $\begin{array}{l}\mathbf{J} \\
\text { ठु }\end{array}$ & $a$ & 19 & $1=$ & $\approx$ & $m$ & $1 \pm$ & 12 & 10 \\
\hline
\end{tabular}




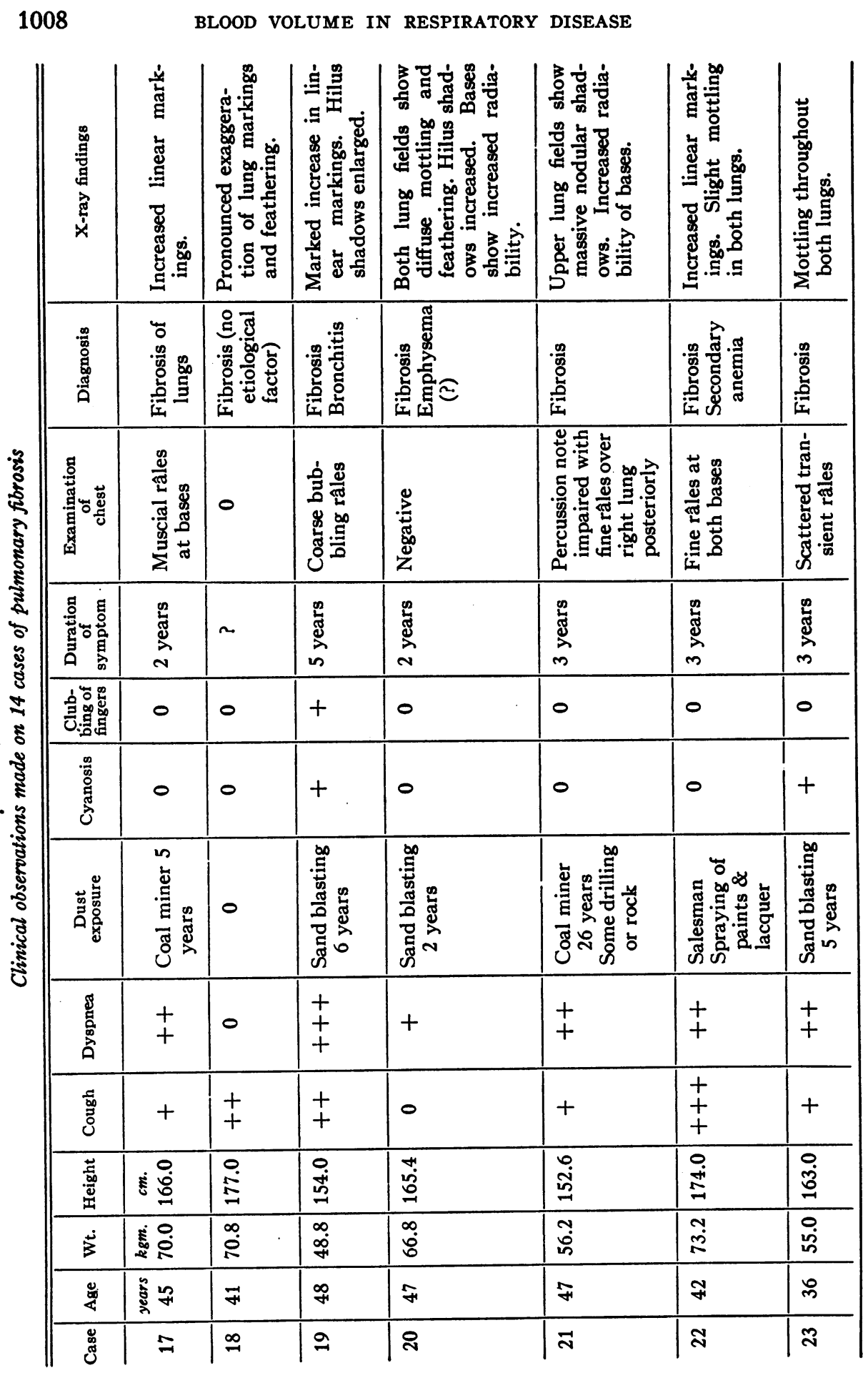


N. L. KALTREIDER, A. HURTADO AND W. D. W. BROOKS 1009

\begin{tabular}{|c|c|c|c|c|c|c|c|}
\hline 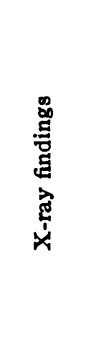 & 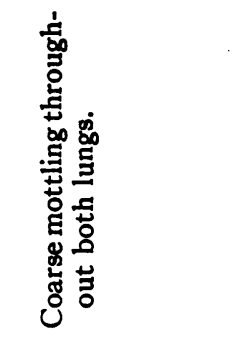 & 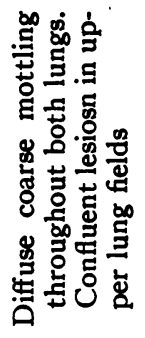 & 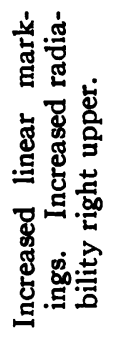 & 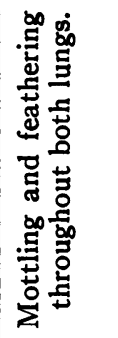 & 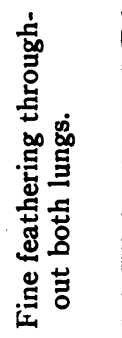 & 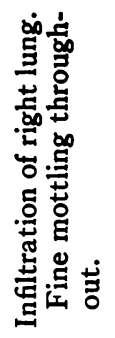 & 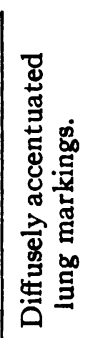 \\
\hline 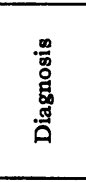 & 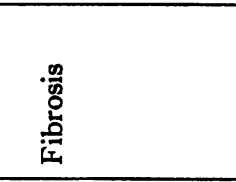 & 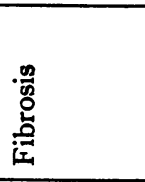 & 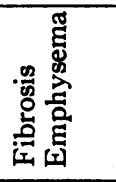 & 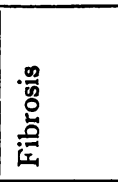 & 量 & 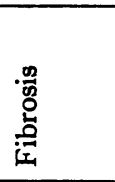 & $\begin{array}{l}.0 \\
0 \\
0 \\
0 \\
0\end{array}$ \\
\hline 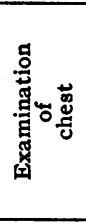 & 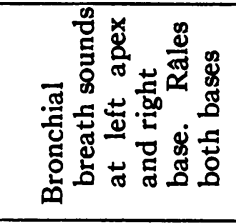 & 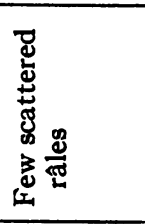 & 莺 & 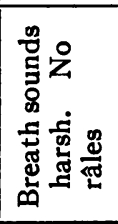 & 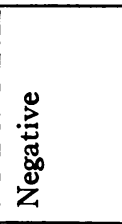 & 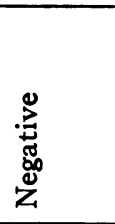 & 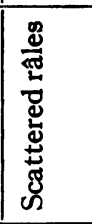 \\
\hline 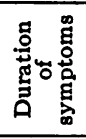 & 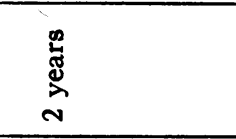 & $\underset{\beth}{\$}$ & 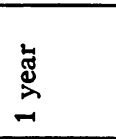 & 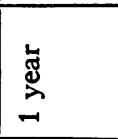 & 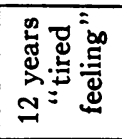 & 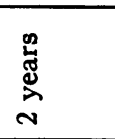 & 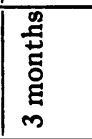 \\
\hline 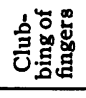 & 0 & 0 & 0 & $\begin{array}{l}+ \\
+\end{array}$ & + & 0 & 0 \\
\hline 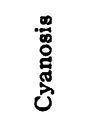 & 0 & + & + & $\begin{array}{l}+ \\
+ \\
+\end{array}$ & $\begin{array}{l}+ \\
+ \\
+\end{array}$ & + & 0 \\
\hline 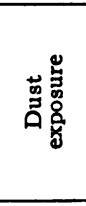 & 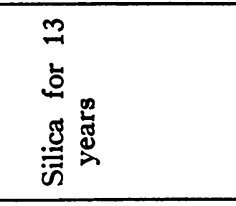 & 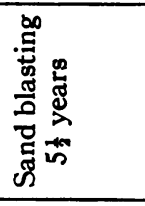 & 0 & 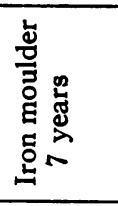 & 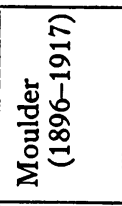 & 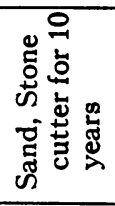 & 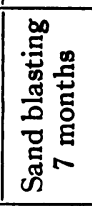 \\
\hline 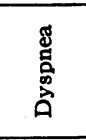 & $\begin{array}{l}+ \\
+ \\
+\end{array}$ & + & + & $\begin{array}{l}+ \\
+ \\
+\end{array}$ & 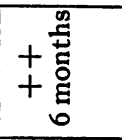 & + & + \\
\hline 范 & $\begin{array}{l}+ \\
+ \\
+\end{array}$ & + & + & + & 0 & + & + \\
\hline 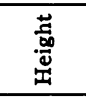 & ह & $\stackrel{n}{\infty}$ & $\begin{array}{l}0 \\
\infty \\
0 \\
0 \\
0\end{array}$ & $\begin{array}{l}0 \\
\infty \\
\stackrel{0}{\circ} \\
\rightarrow\end{array}$ & 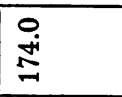 & $\stackrel{n}{I}$ & $\begin{array}{l}0 \\
\stackrel{2}{0} \\
0\end{array}$ \\
\hline$\dot{3}$ & 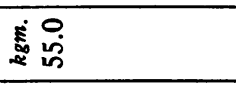 & $\begin{array}{l}0 \\
0 \\
\end{array}$ & $\stackrel{0}{0}$ & ลี & ڤ్ & \begin{tabular}{|l|} 
\\
0 \\
0 \\
0
\end{tabular} & ๙்ุ \\
\hline$\ddot{8}$ & ํㅐํ ₹ & $\tilde{m}$ & $\stackrel{\infty}{\infty}$ & in & in & นุ & స్ \\
\hline 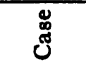 & $\nexists$ & $\stackrel{2}{\sim}$ & ㅁ & $\hat{N}$ & 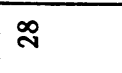 & নి & ల్ల \\
\hline
\end{tabular}


of symptoms varied from 3 months to 12 years. The duration of exposure to silica in the patients suspected of having pneumonokoniosis varied from 7 months to 25 years. One patient (Case 28) complained of muscular pains and dizziness. Cyanosis was observed in half and clubbing of the fingers in 3 of the 14 cases. The blood pressure was within normal limits except in Cases 19 and 30 where it was 140/100 and 160/105 respectively. Electrocardiograms showed left ventricular preponderance in Cases 17,18 and 26 while a preponderance of the right ventricle was found in only one (Case 17). The spleen was not felt in any of the subjects.

\section{Results}

Emphysema. In Table VI are presented the individual and the mean values for the total volume and the volume per kilogram of body weight for the blood, plasma, cells and circulating hemoglobin. The total blood volume varied between 3.18 and 7.27 liters with a mean value of 4.87 liters. The mean value of the blood volume per kilogram of body weight was 76.7 cc., a figure somewhat below that of the normal subjects. The extremes were 68.4 and $91.6 \mathrm{cc}$. All the observations fell within normal limits as shown in Figure 1. The mean value of the plasma volume per kilogram was slightly below that of the normal, $40.7 \mathrm{cc}$. as compared with $42.8 \mathrm{cc}$. On the other hand the mean value of cell volume per kilogram in the pathological cases was $35.5 \mathrm{cc}$., which was approximately the same as that of the normal group. Only two observations were slightly outside the normal limits as shown in Figure 1. The mean value for the hemoglobin per kilogram of body weight was 12.5 , slightly below the nor$\mathrm{mal}$; with 2 cases beyond the lower limits of normal. (Figure 2.) The hemoglobin per $100 \mathrm{cc}$. of blood varied between 11.6 and 18.7 grams with a mean of 16.2 grams, which is identical with that of the normal. The hematocrit readings of cell volume also varied markedly between 38.5 to 52.6 per cent with a mean value of 46.3 per cent. We find then, in this group of cases with emphysema, a slight though not significant decrease in the blood and plasma volume and the hemoglobin per kilogram of body weight, while the cell volume remains the same.

Fibrosis. The results in a study of 14 cases of chronic pulmonary fibrosis are tabulated in Table V. In this group we find a definite increase in the mean values of blood and cell volume per kilogram of body weight, the former mean value being $88 \mathrm{cc}$. as compared with $79.1 \mathrm{cc}$. of the normal group; while the latter value was $45.2 \mathrm{cc}$. compared with the normal value of $35.8 \mathrm{cc}$. It is evident from Table VI and Figure 1 that the mean values of the whole group are high due to marked increase in the volume of the blood and cells in three (Cases 19, 27 and 28) of the fourteen cases while in the remaining ones the values obtained were within normal limits. The mean value for the plasma volume was 42.4 cc., approximately that of the 
N. L. KALTREIDER, A. HURTADO AND W. D. W. BROOKS

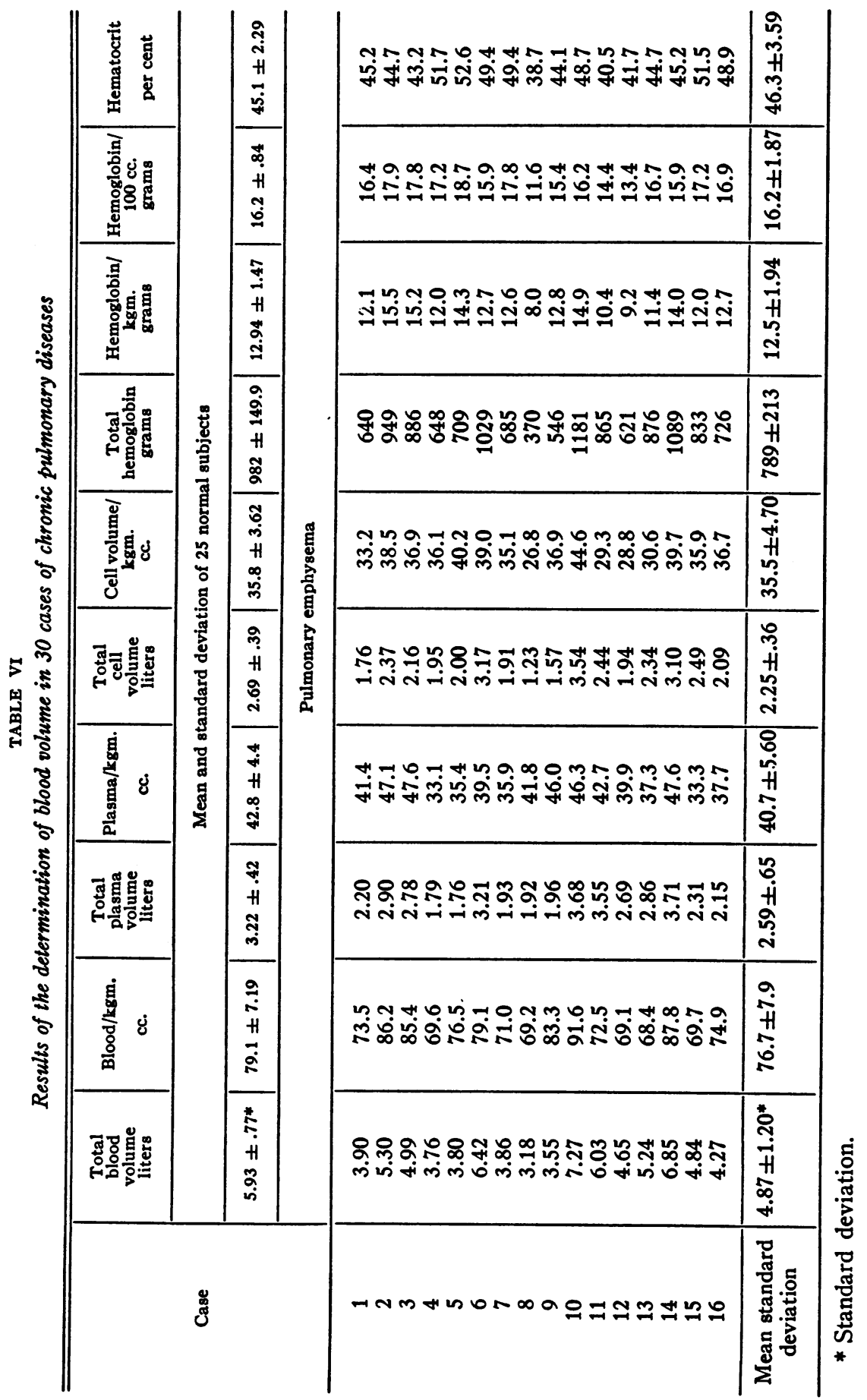




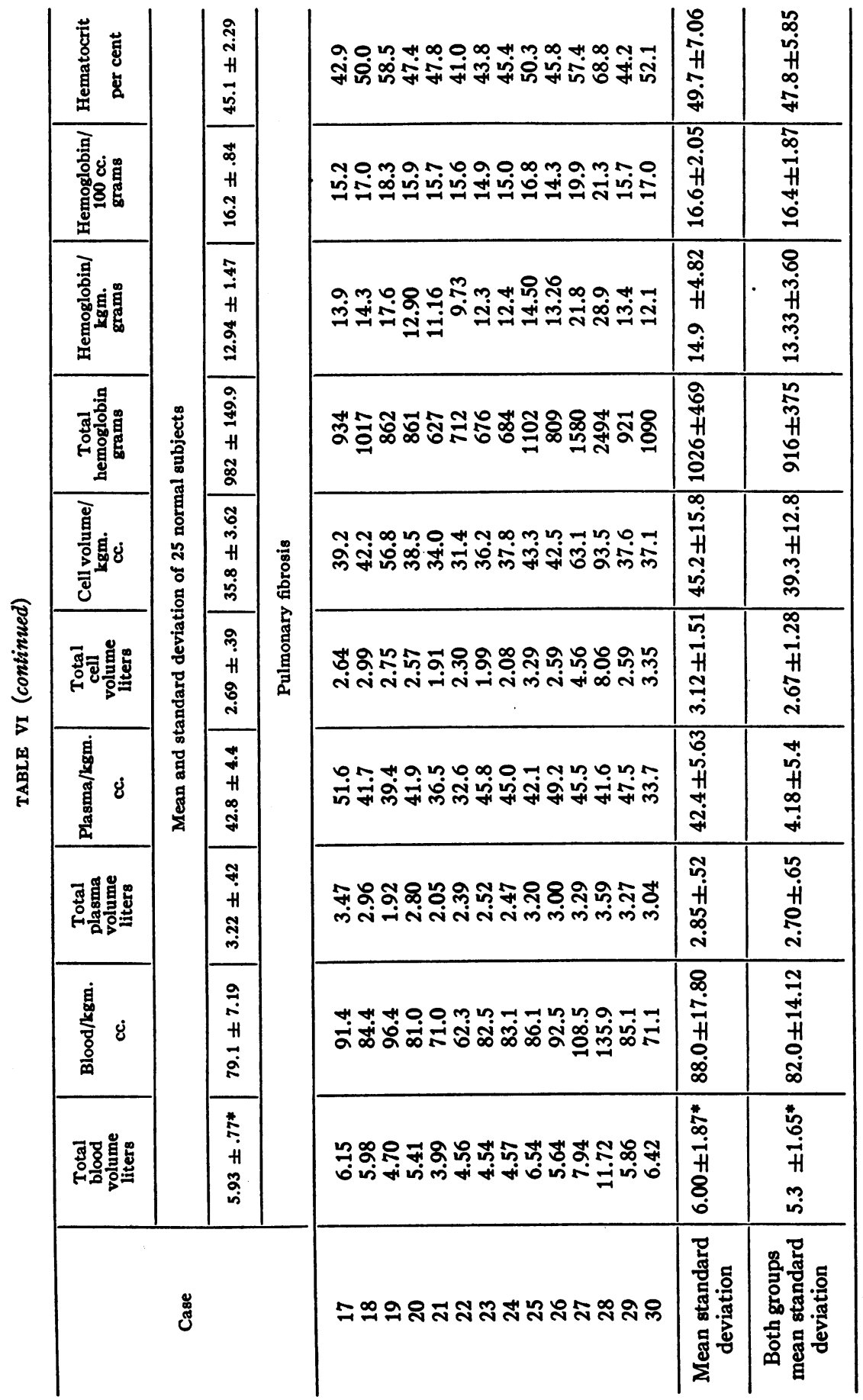




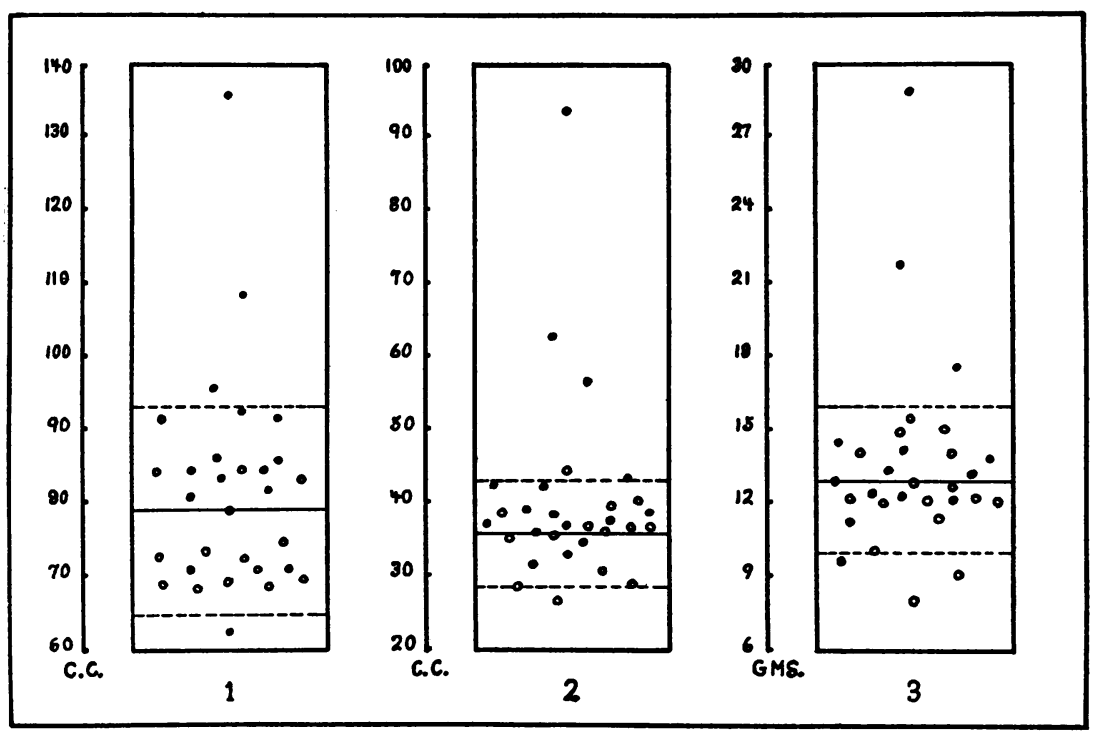

Fig. 1. Determinations of Blood and Cell Volume and Hemoglobin per Kilogram of Body Weight in 30 Cases of Chronic Respiratory DisEASES.

The mean values for the normal subjects are represented by the unbroken lines, while the broken ones show the deviations from the mean. Circles indicate cases with emphysema. Dots, those with fibrosis.

1. Blood volume. 2. Cell volume. 3. Hemoglobin.

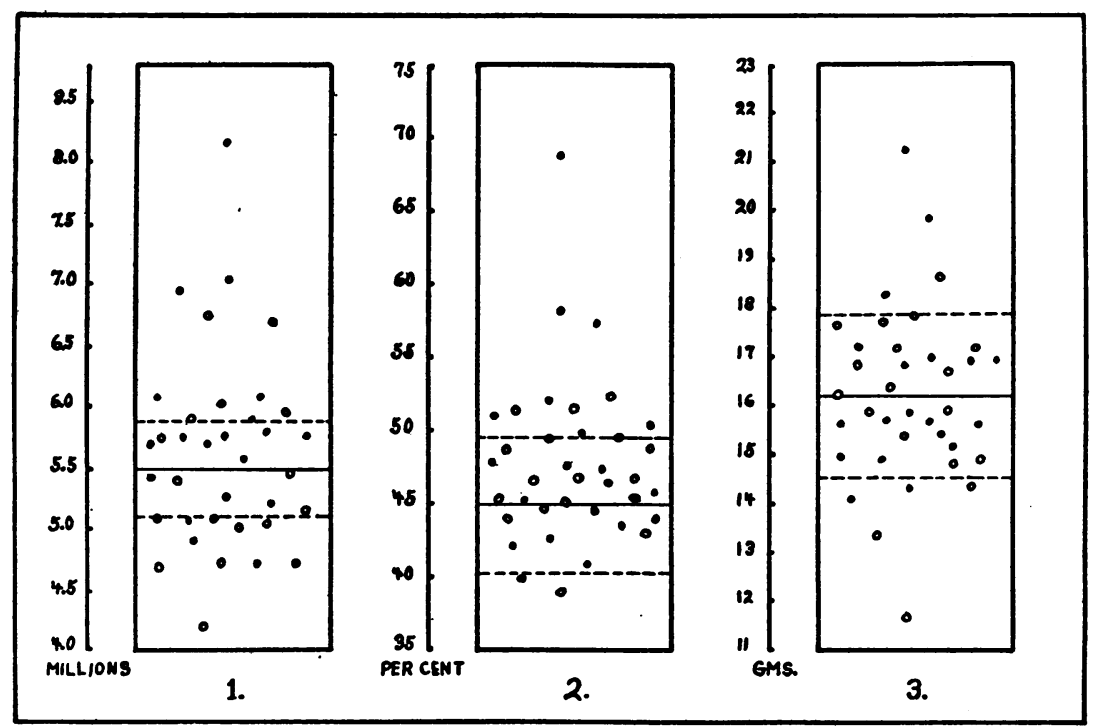

Fig. 2. Erythrocyte Count, Hematocrit, and Hemoglobin per 100 cc. of Blood in 30 Cases of Pulmonary Emphysema and Fibrosis

1. Red blood cell count per cubic millimeter.

2. Hematocrit.

3. Hemoglobin per $100 \mathrm{cc}$. of blood. 
normal group. Although the values for the hemoglobin per kilogram of body weight varied widely, the mean value was 2 grams higher than that of the normal subjects. Here again Cases 19, 27 and 28 were definitely above the normal limits while Case 22 was slightly below, as illustrated in Figure 1. Likewise the mean value of the hemoglobin per 100 cc. of blood was somewhat above that of the normal group, while in the same three cases mentioned above the hemoglobin was elevated. Along with the above findings we found the mean for the hematocrit somewhat increased, 49.7 per cent as compared with the normal of 45.1 per cent, while 6 of the cases showed an abnormally high value (Figure 2.)

The calculated values based on body weight, and the observed values for the total blood, plasma and cell volume and hemoglobin in the 30 pathological cases are represented in Figure 3. This shows graphically

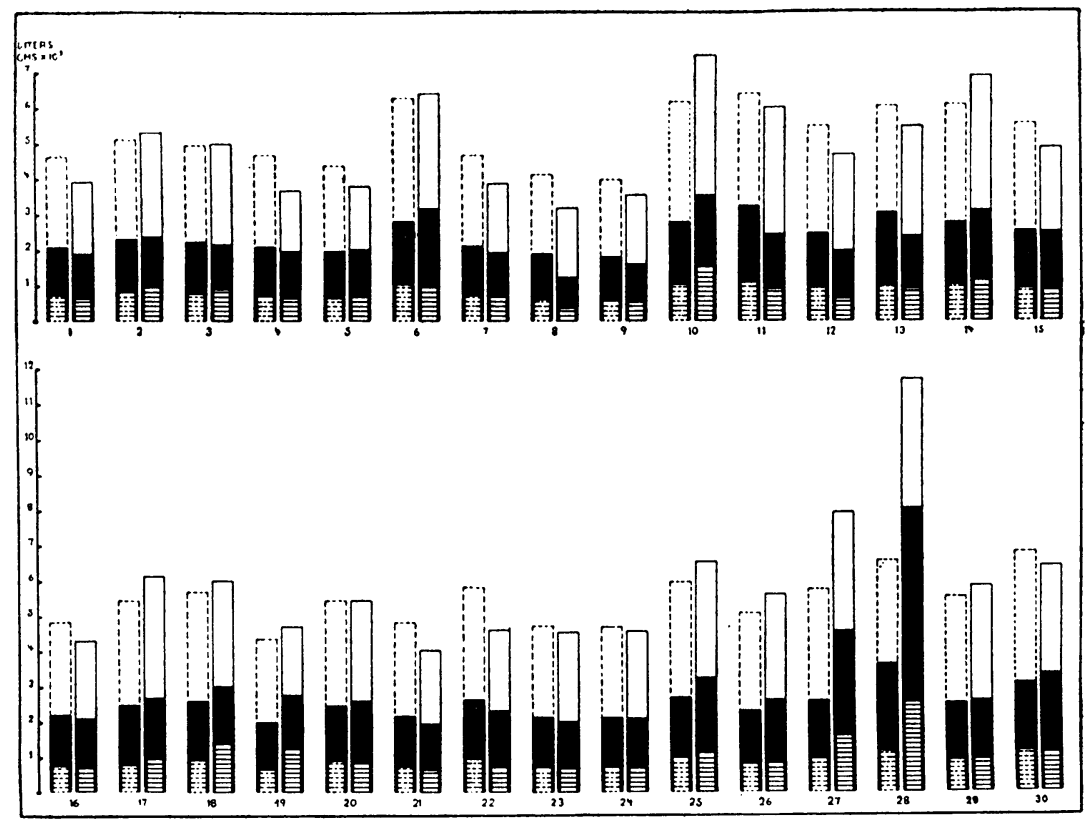

Fig. 3. Calculated and Observed Blood Volume in Cases of Pulmonary Emphysema and Fibrosis

Cases 1 to 16 inclusive are those with emphysema; from 17 to 30 inclusive, cases of fibrosis. Each case is represented by two columns. The one on the left, with broken lines is the predicted while the right hand column is the observed volume. The white area is plasma; the black, cell volume while the transverse lines represent the total hemoglobin.

that there are no significant variations in cases of pulmonary emphysema (Cases 1 to 17) while in the group with pulmonary fibrosis Cases 27 and 
28 show evidence of hydremic plethora ${ }^{4}$ and Case 19 shows an increase in the blood and cell volume and hemoglobin while the plasma is slightly reduced.

When the two groups are taken together we find that the mean values for the blood and cell volume, the total hemoglobin and the hematocrit are slightly above those observed in the normal subjects, while the plasma volume is slightly decreased; thus showing slight concentration of the blood.

The mean values for the blood, plasma and cell volume and circulating hemoglobin expressed in terms of cubic centimeters per kilogram of body weight for the three groups (normal, emphysema, and fibrosis) are compared graphically in Figure 4. A slight decrease in the blood and plasma

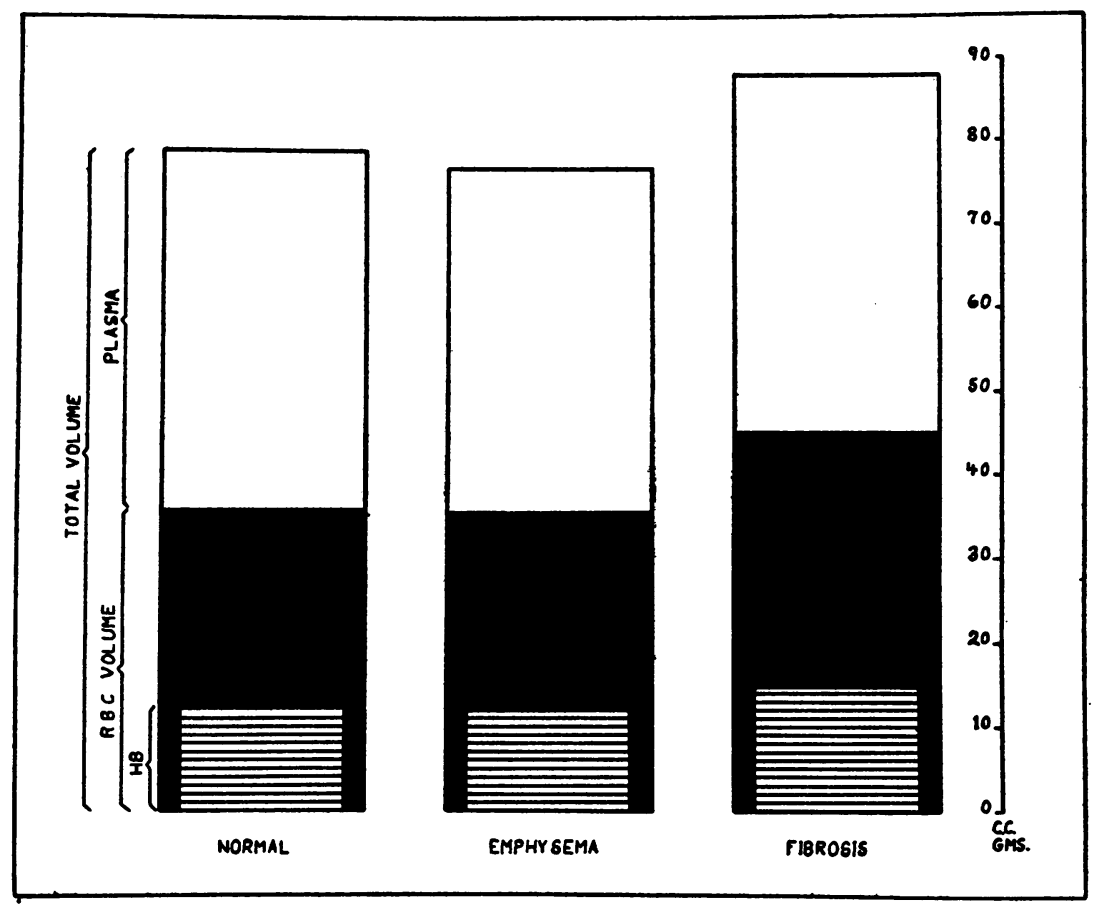

Fig. 4. Mean Values for the Blood Volume and Its Components PER KILOGRAM OF BODY WEIGHT

volume is evident in the cases of emphysema while the cell volume and hemoglobin are practically identical with the normal group. On the other hand, the cases with pulmonary fibrosis show an increase in mean values of 11 per cent in the blood volume, of 26 per cent in the cell volume and of 15.5 per cent in hemoglobin as compared with the normal, while no abnormality in the mean plasma volume was observed.

4 Same as polycythemic hypervolemia used by Rowntree, designating increase of the volume of blood and cells above the limits for normal individuals. 


\section{RELATIONSHIP OF BLOOD VOLUME TO VARIOUS FACTORS}

Duration and severity of symptoms. Those cases which showed an increased blood and cell volume had moderate or severe respiratory disability, but not all the patients complaining of marked dyspnea and severe asthmatic attacks showed abnormality in the volume of the blood. No definite relationship could be demonstrated between alteration in the blood volume and duration of symptoms. For instance, in Case 27 who had had symptoms for only one year, a blood volume of $108.5 \mathrm{cc}$. per kilogram of body weight was found.

Arterial oxygen saturation. The carbon dioxide and oxygen content and oxygen combining power of the arterial blood was determined in 22 of these cases. All except 6 were found to have an oxygen saturation less than 93 per cent, with extremes of 67 and 98 per cent. The oxygen saturation in Cases 19, 27 and 28 which showed an increase in blood volume was found to be very low, $80.6,67.2$ and 81.1 per cent respectively, while in Cases 1, 2, 3 and 11 in which the arterial oxygen saturation ranged between 74 and 84 per cent there was no increase in blood volume. In the group of cases in which the arterial oxygen saturation was below 90 per cent, the blood volume per kilogram body weight was increased as shown in Table VII.

Pulmonary capacity. That no relationship exists between decrease in vital capacity and changes in the blood volume, hematocrit and hemoglobin is shown in Table VII. The decrease in vital capacity varied between 16.5 and 71.8 per cent, all values being beyond the limit of normal variation which is considered to be 15 per cent. No correlation was found between the ratio of residual air to total pulmonary capacity and alterations in the blood volume or any of its components. The ratio varied between 23.6 and 73.4 per cent with only 8 cases or 35 per cent within normal limits.

\section{CHARACTERISTICS OF THE ERYTHROCYTES}

Very few studies have been made on the characteristics of the red blood cells of patients suffering from pulmonary emphysema and fibrosis. In 22 cases of pulmonary emphysema Price-Jones (16) found the size of the red cell larger than in a corresponding group of normal subjects used as controls. The mean diameter of the erythrocytes in the former group was $7.69 \mu$ while in the latter it was $7.24 \mu$, an increase which the author believed significant. Lemon (15) found an increase of 20 per cent in the corpuscular hemoglobin in 12 cases of chronic pulmonary emphysema, while the volume of the individual cells was not significantly increased. The average number of red blood cells in each cubic millimeter was 5.02 millions with a range between 4.05 and 6.86 millions.

The results of a study of the characteristics of the erythrocytes in 36 cases of pulmonary emphysema and fibrosis are summarized in Table VIII. 


\begin{tabular}{|c|c|c|c|}
\hline & 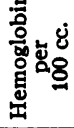 & 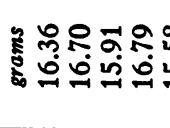 & 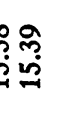 \\
\hline & 焉 & 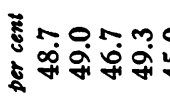 & جุ \\
\hline & 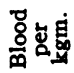 & نْ & مُ \\
\hline & 总哭 & banm. & ph \\
\hline 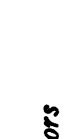 & 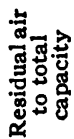 & 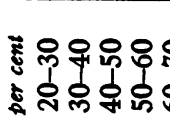 & $\begin{array}{l}28 \\
1 \\
1 \\
0\end{array}$ \\
\hline$\frac{3}{3}$ & 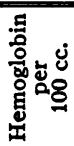 & 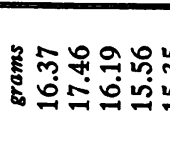 & 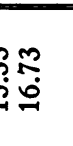 \\
\hline हूँ & 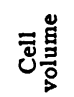 & 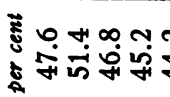 & 稣 \\
\hline 붕 & 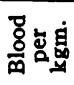 & ن & $\frac{1}{\infty}$ \\
\hline 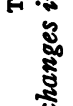 & 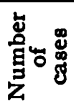 & n $n$ in & in \\
\hline है & 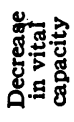 & 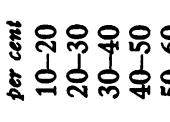 & ?앙 \\
\hline & 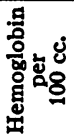 & 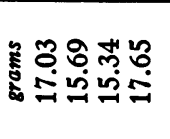 & 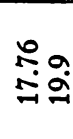 \\
\hline & ฮัّ & 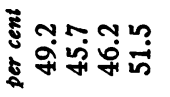 & 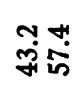 \\
\hline & 郎岁息 & 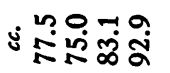 & 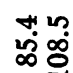 \\
\hline & 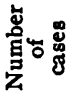 & $+10-1$ in & $\leadsto$ \\
\hline & 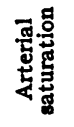 & 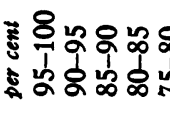 & 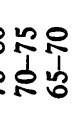 \\
\hline
\end{tabular}




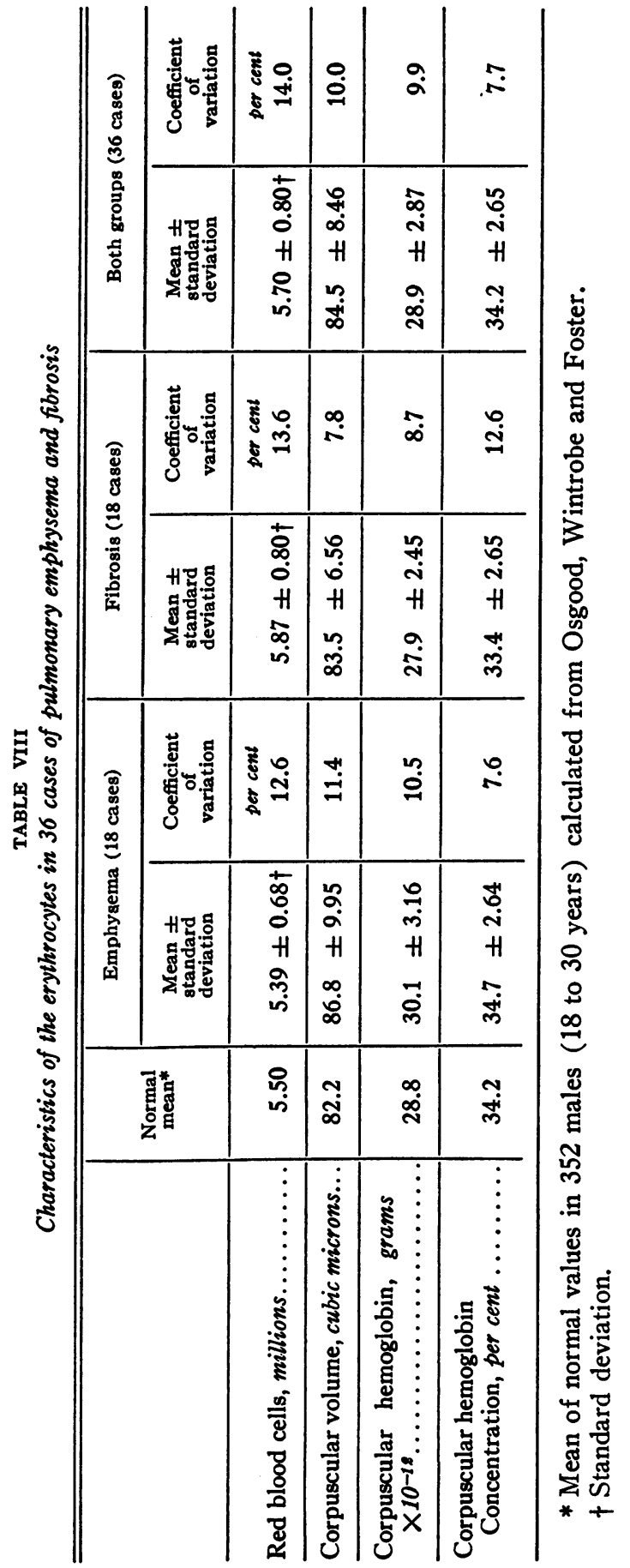


The blood volumes of 30 of these cases are reported above. The mean value for the number of red cells per c.mm. in both groups was 5.70 millions, a slight increase over that of the normal (5.50 millions) calculated in 352 males reported by Osgood (17), Wintrobe (18), and Foster and Johnson (19). The mean value for the group with emphysema was 5.39 millions a figure slightly below the normal value while that for the group with fibrosis was 5.87 millions, which is definitely above the normal. The extremes in the two groups were 4.2 and 8.17 millions. As illustrated in Figure 2, an equal number of cases fell below as above the limits of normal.

The corpuscular volume for both groups was increased, the mean value being $86.8 \mu^{3}$ for the cases showing emphysema and $83.5 \mu^{3}$ for the group exhibiting fibrosis, while for the whole group it was $84.5 \mu^{3}$ (normal value 82.2 cubic microns).

Correspondingly, the corpuscular hemoglobin for the cases with fibrosis was slightly lower than for those with emphysema, having mean values of 27.9 and 30.1 micromicrograms (gm. $\times 10^{-12}$ ) respectively. (Normal value $28.8 \mathrm{gm} . \times 10^{-12}$.)

As shown in Table VIII the mean for the corpuscular hemoglobin concentration in both groups was identical with that of the normal. The mean value in cases with emphysema was slightly above, while in the group with fibrosis it was just below the normal value.

TABLE IX

Relation of the number of erythrocytes to their size and hemoglobin concentration

\begin{tabular}{c|c|c|c|c|c|c}
\hline \hline $\begin{array}{c}\text { Number } \\
\text { of } \\
\text { erythrocytes }\end{array}$ & Cases & $\begin{array}{c}\text { Hemoglobin } \\
\text { per } \\
100 \text { cc. }\end{array}$ & $\begin{array}{c}\text { Corpuscular } \\
\text { volume }\end{array}$ & $\begin{array}{c}\text { Corpuscular } \\
\text { hemoglobin }\end{array}$ & $\begin{array}{c}\text { Corpuscular } \\
\text { hemoglobin } \\
\text { concen- } \\
\text { tration }\end{array}$ & $\begin{array}{c}\text { Percentage } \\
\text { of red } \\
\text { blood } \\
\text { cells } \\
\text { hematocrit }\end{array}$ \\
\hline million & grams & cubic microns & grams $\times 10^{-12}$ & per cent & per cent \\
4.5 & 5 & 15.1 & 93.3 & 30.4 & 32.4 & 44.5 \\
5.0 & 11 & 16.2 & 88.8 & 31.0 & 34.9 & 46.3 \\
5.5 & 11 & 15.7 & 81.2 & 27.3 & 33.6 & 46.8 \\
6.0 & 3 & 16.8 & 81.4 & 28.0 & 34.5 & 49.1 \\
6.5 & 3 & 18.3 & 74.3 & 26.8 & 36.4 & 50.7 \\
\hline
\end{tabular}

Table IX shows the variation of the cellular characteristics, hemoglobin per $100 \mathrm{cc}$. of blood, and the hematocrit in these cases according to the red cell count. Here was found the inverse correlation of the corpuscular hemoglobin and volume to the red cell count, such as occurs in normal subjects ; in other words as the red cell count increased the cells became smaller and contained less hemoglobin; both of these changes being proportional, the corpuscular hemoglobin concentration remained the same. 


\section{DISCUSSION}

Investigations of the blood volume in cases of chronic pulmonary disease are important from the standpoint of the various theories advanced to explain the production of polycythemia and its relation to a low oxygen tension. The development of these ideas is closely correlated with and based upon observations made at high altitudes, or in chambers where the barometric pressure is lowered to simulate the effects of higher levels. A brief review of the results obtained by such investigations will be useful in understanding the present status of the pathogenesis of polycythemia.

Since the discovery by Paul Bert (20) in 1882 (confirmed a few years later by Viault (21)), that the blood of animals living in the Peruvian Andes has an increased number of red blood cells and an increased capacity for combining with oxygen, practically all investigators agree that such a change occurs both in animals and man at low barometric pressure, although its intensity varies markedly in different individuals. Miescher (22) in 1893 formulated the theory that oxygen deficiency in the bone marrow was the stimulus for the formation of new red cells. His idea has had general acceptance and was substantiated indirectly both by the studies of Bence (23) who claimed that inhalation of oxygen decreases the erythrocytosis which one encounters at high altitudes, and by the observations of Dersca and Valter (24) who succeeded in decreasing the number of red cells in the peripheral blood of patients with anoxemia by the intravenous injection of oxygen. The work of Barcroft and his coworkers (25) demonstrating that the spleen is a storehouse for red cells which are liberated and thrown into the circulation in conditions of oxygen want, has thrown new light on the explanation of erythrocytosis at high altitudes. At the present time most observers agree that this increase in red cells and hemoglobin is primarily produced by the contraction of the spleen, liberating the red cells stored in its pulp, and possibly also by releasing the supply of red cells stored in the bone marrow ( $\mathrm{McNee}(26)$ ). Secondarily, if the condition of oxygen want persists, signs of bone marrow activity appear and the increase in the number of red cells may then be correlated with the signs of overactivity of the hematopoietic system. However, because so few estimations of blood volume have been made, it is still a debated point whether this erythrocytosis in new comers and residents at a high altitude is associated with a real increase in the total volume of blood cells or with changes in their concentration in the blood. In 1910 Douglas (27) made observations by means of the carbon monoxide method on Teneriffe (altitude 7,000 feet) and was unable to detect any changes. The Pike's Peak Expedition (by Haldane and others (28)) found evidence of a temporary concentration of red blood cells during the first few days and later a true increase in the total volume of cells. Smith, Belt, Arnold and Carrier (29) found minimal changes in the blood volume 
after a brief stay at Long Lake in the Sierra Nevada Mountains (altitude 11,000 feet), and Lippmann (30) and Laquer (31) found very slight alterations at Davos (5,100 feet). Monge (32) has described the existence of a primary polycythemia in the residents of the Peruvian Andes, but studies of the blood volume have not been made in such cases. It is evident from this review that our knowledge concerning the true nature of the erythrocytosis that man develops at high altitude is insufficient. Whether or not there is an increase in the blood volume similar to that found in cases of polycythemia vera at sea level is not known. Further studies in this connection will undoubtedly help solve this interesting problem.

Harrop and Heath (33), who called attention to the marked resemblance of the symptoms of "mountain sickness" to those found in cases of polycythemia vera, advanced the opinion that polycythemia vera may be due to lowered oxygen tension of the arterial blood caused by a change in the alveolar wall, resulting in decreased oxygen diffusion. In three cases of polycythemia they observed a lowering of the arterial oxygen saturation after exercise. The results of these observations would naturally suggest that polycythemia should be found more frequently in cases of chronic pulmonary diseases, in which pathological alterations in the lung parenchyma exist producing a decrease in the oxygen saturation of the arterial blood. That such is not commonly the case is a well known clinical fact; however, actual studies of the blood volume have been reported in only a few cases. Plesch (14) and Uhlenbruck (5) found an increase of the blood volume in a small number of cases with chronic bronchitis and emphysema, but the degree of anoxemia was not determined. Lemon (15), who studied 12 cases of chronic pulmonary emphysema, did not find any significant increase in the blood and cell volume, in spite of a low value (average 88 per cent) of the arterial oxygen saturation in seven of his cases. From these studies Lemon concluded that there is no relationship between the development of polycythemia and pathological alterations in the alveolar wall. It is clear that the evidence against the relationship between development of polycythemia and pulmonary changes resulting in a decreased oxygen tension is rather negative in character and inconclusive in view of the limited number of cases studied.

A point frequently lost sight of is that the response of the bone marrow to any stimulus calling for the formation of new red cells is extremely variable from individual to individual. This fact is easily demonstrated by the response of the blood to low barometric pressures. Although subjects are exposed to exactly the same stimulus, some will exhibit a great increase in the circulating hemoglobin and red cells, while others will show only a slight increase. This difference is also found among the residents at high altitude (Hurtado (34)). One can not dismiss the hypothesis that 
a case of polycythemia vera represents a pathological response of a very sensitive bone marrow to a slight or moderate decrease in the oxygen tension of the arterial blood, and that the background of such an occurrence is the existence of anatomical alterations in the lung parenchyma. In a large majority of cases such alterations may not be sufficient to cause such an abnormal response on the part of the hematopoietic system. It is significant in this connection that in most cases of polycythemia vera in which the arterial blood has been studied, the oxygen saturation was found to be lower than normal.

That we found a hydremic plethora in three cases of pulmonary fibrosis is quite significant and indicates that perhaps these two conditions will be found to be more frequently associated if a greater number of cases are studied. It is also significant that in these three cases the arterial oxygen saturation was markedly decreased. It is fair to assume from the history that in these cases the fibrosis of the lung resulting from inhalation of silica probably preceded the development of the polycythemia. In two of these cases the signs and symptoms with the exception of an enlarged spleen were identical with those of so-called "primary" polycythemia or polycythemia vera. These results indicate that, whereas in most cases of chronic pulmonary diseases there is no significant change in the volume of the blood except possibly slight concentration even though anoxemia exists, there are, however, occasional cases in which a hydremic plethora develops closely simulating polycythemia vera. It is interesting that this change was found only in cases with pulmonary fibrosis. Our cases with emphysema, as well as those reported by Lemon (15), in spite of the existence of anoxemia showed normal blood findings. This cannot be explained in the light of our present knowledge. Whether or not the nature of the pathological changes in the lungs has some relation to the development of polycythemia is unknown.

\section{Summary and Conclusions}

Determinations of blood and plasma volumes were made on 25 normal male subjects whose average age was 26 years. Intravenous injection of brilliant vital red was used in the estimation of the plasma volume. Studies were made also in 16 cases of pulmonary emphysema and in 14 cases of pulmonary fibrosis. The determinations were made in conjunction with clinical observations and measurements of the pulmonary capacity and of the gas content of the arterial blood. From the results of this investigation the following conclusions are drawn:

1. In a group of normal males there were marked variations in the values for the total blood volume and its components. There was a high and significant correlation between the volume of the blood and body weight and on this basis the expected values for the blood volume in the pathological cases were calculated. 
2. In a group of cases with varying degrees of pulmonary emphysema, no significant alterations from the normal were found in the plasma, blood and cell volume or in the total circulating hemoglobin per kilogram of body weight.

3. The mean values for the cell volume and total hemoglobin were definitely increased in the group of cases with pulmonary fibrosis. This was due to marked alterations found in three cases, and not to a consistent increase in all the subjects. The volume of the plasma was normal.

4. No definite correlation was found between the severity and duration of symptoms and the increase in the blood volume.

5. A decreased arterial oxygen saturation was found in the three cases which showed marked alterations in the blood volume, but in the remaining cases no correlation was demonstrated between the degree of anoxemia and the blood findings.

6. Likewise no definite relationship was found between alterations in the blood volume and changes in the pulmonary capacity.

7. The mean values for the grams of hemoglobin and the red cell volume per $100 \mathrm{cc}$. of blood were within normal limits in the group of cases with pulmonary emphysema, but there was a moderate increase in those with pulmonary fibrosis. Marked individual variations were observed.

8. The mean value for the red cell count was found to be within normal limits in both groups of cases, those with pulmonary emphysema and those with fibrosis. No significant changes were demonstrated in the volume or hemoglobin content of the red blood cells.

\section{BIBLIOGRAPHY}

1. Mendershausen, A., Blutmengenbestimmungen mit der Kongorotmethode. Ztschr. f. klin. Med., 1923, 97, 468.

2. Seyderhelm, R., and Lampe, W., Zur Frage der Blutmengenbestimmung. III. Colorimetrische Blutmengenbestimmung mit Trypanrot. Ztschr. f. d. ges. exper. Med., 1923, 35, 177.

3. Rusznyák, S., Untersuchungen Zur Frage des Gesamtblutmenge des Menschen unter normalen und pathologischen Verhältnissen. Deutsches Arch. f. klin. Med., 1927, 157, 186.

4. Rowntree, L. G., and Brown, G. E., The volume of the blood and plasma in health and disease. W. B. Saunders Co., Philadelphia, 1929.

5. Uhlenbruck, P., and Vogels, Zum Problem der Zirkulierenden Plasmamenge (Blutmenge) bei Kreislaufstörungen. Ztschr. f. klin. Med., 1931, 118, 172.

6. Sparks, M. I., and Haden, R. L., The blood volume in chronic arthritis. Am. J. M. Sc., 1932, 184, 753.

7. Keith, N. M., Rowntree, L. G., and Geraghty, J. T., A method for the determination of plasma and blood volume. Arch. Int. Med., 1915, 16, 547.

8. Fleischer-Hanson, C. C., Determinations of the blood volume in human beings. IV. Results with the vital red method. Skandinav. Arch. f. Physiol., 1930, 59, 257. 
9. Hooper, C. W., Smith, H. P., Belt, A. E., and Whipple, G. H. Blood volume studies. I. Experimental control of a dye blood volume method. Am. J. Physiol., 1920, 51, 205.

10. Van Slyke, D. D., Gasometric determination of the oxygen and hemoglobin of the blood. J. Biol. Chem., 1918, 33, 127.

11. Hurtado, A., and Boller, C., Studies of total pulmonary capacity and its subdivisions. I. Normal, absolute and relative values. J. Clin. Invest., $1933,12,793$.

12. Hurtado, A., and Fray, W. W., Studies of total pulmonary capacity and its subdivisions. II. Correlation with physical and radiological measurements. J. Clin. Invest., 1933, 12, 807.

13. Wintrobe, M. M., Blood of normal men and women. Erythrocyte counts, hemoglobin and volume of packed red cells of 229 individuals. Bull. Johns Hopkins Hosp., 1933, 53, 118.

14. Plesch, J., Untersuchungen über die Physiologie und Pathologie der Blutmenge. Ztschr. f. klin. Med., 1922, 93, 241.

15. Lemon, W. S., A study of the effect of chronic pulmonary diseases on the volume and composition of the blood. Ann. Int. Med., 1929, 3, 430.

16. Price-Jones, C., The size of red blood cells in emphysema. J. Path. and Bact., 1921, 24, 326.

17. Osgood, E. E., Hemoglobin, color index, saturation index and volume index standards. Redeterminations based on the findings in 137 healthy young men. Arch. Int. Med., 1926, 37, 685.

18. Wintrobe, M. M., and Miller, M. W., Normal blood determinations in the South. Arch. Int. Med., 1929, 43, 96.

19. Foster, P. C., and Johnson, J. R., Oxygen capacity and hemoglobin content of normal blood of men. Proc. Soc. Exper. Biol. and Med., 1931, 28, 929.

20. Bert, Paul, Sur la richesse en hémoglobine du sang des animaux vivant sur les hauts lieux. Comptes rend. Acad. d. sc., Par., 1882, 94, 805.

21. Viault, F., Sur l'augumentation considérable du nombre des globules rouges dans le sang chez les habitants des hauts plateaux de l'Amerique du Sud. Comptes rend. Acad. d. sc., Par., 1890, 111, 917.

22. Miescher, F., Ueber die Beziehungen zwischen Meereshoehe und Beschaffenheit des Blutes. Cor. Blatt. f. Schweitz. Artze, 1893, 23, 809.

23. Bence, J., Drei Fälle von Polyglobulie mit Milztumor. Deutsche med. Wchnschr., 1906, 32, 1451.

24. Dersca, A., and Valter, V., Les modifications sanguines à la Suite de l'oxygénothérapie Intraveineuse. Paris Med., 1929, 2, 314.

25. Barcroft, J., and Stephens, J. G., Observations upon the size of the spleen. J. Physiol., 1927, 64, 1.

26. McNee, J. W., The spleen: its structure, functions and diseases. Lancet, $1931,1,1009$.

27. Douglas, C. G., The determination of the total oxygen capacity and blood volume at different altitudes by the carbon monoxide method. J. Physiol., 1910, 40, 472.

28. Douglas, C. G., and Haldane, J. S., Henderson, Y., Schneider, E. C., Physiological observations made on Pike's Peak, Colorado, with special reference to adaptation to low barometric pressures. Phil. Tr. Roy. Soc., $1913,203,185$.

29. Smith, H. P., Belt, A. E., Arnold, H. R., and Carrier, E. B., Blood volume changes at high altitude. Am. J. Physiol., 1925, 71, 395. 
N. L. KALTREIDER, A. HURTADO AND W. D. W. BROOKS 1025

30. Lippmann, A., Blutzusammensetzung und Gesamtblutmenge bei Hochgebirgsbewohnern. Klin. Wchnschr., 1926, 5, 1406.

31. Laquer, F., Untersuchungen der Gesamtblutmenge im Hochgebirge mit der Griesbachschen Kongorotmethode. Klin. Wchnschr., 1924, 3, 7.

32. Monge, C., Les Erythrémies de l'Altitude. Masson et Cie, Paris, 1929.

33. Harrop, G. A., and Heath, E. H., Pulmonary gas diffusion in polycythemia vera. J. Clin. Invest., 1927, 4, 53.

34. Hurtado, A., Studies at high altitude. Blood observations on the Indian natives of the Peruvian Andes. Am. J. Physiol., 1932, 100, 487. 